Article

\title{
Effects of Nitrogen Forms and Supply Mode on Lipid Production of Microalga Scenedesmus obliquus
}

\author{
Mei An ${ }^{1}$, Li Gao ${ }^{2}$, Wen Zhao ${ }^{1}$, Weiguang Chen ${ }^{1}$ and Ming $\mathrm{Li}^{1}{ }^{1} *$ (]) \\ 1 College of Natural Resources and Environment, Northwest Agriculture and Forestry University, \\ Yangling 712100, China; anmei3624@163.com (M.A.); 748503910@nwafu.edu.cn (W.Z.); \\ 2017011380@nwafu.edu.cn (W.C.) \\ 2 SouthEast Water, 101 Wells Street, Frankston, VIC 3199, Australia; gaoli.nj@gmail.com \\ * Correspondence: lileaf@163.com or lileaf@nwsuaf.edu.cn; Tel.: +86-180-4908-7922; Fax: +86-29-8705-0055
}

Received: 25 December 2019; Accepted: 30 January 2020; Published: 6 February 2020

\begin{abstract}
Optimization of the microalgae culture conditions could significantly reduce the production costs of microalgae-derived biodiesel. In the current study, a new process of adding different forms using the multiple small-dose method was employed. The effects of different forms of nitrogen $\left(\mathrm{NaNO}_{3}, \mathrm{NH}_{4} \mathrm{Cl}\right.$, and $\left.\mathrm{CH}_{4} \mathrm{~N}_{2} \mathrm{O}\right)$ and their concentrations $\left(0.1,0.5,1\right.$, and $\left.2 \mathrm{mg} \mathrm{L}^{-1}\right)$ on the growth and lipid production of Scenedesmus obliquus were studied. Algae density and lipid production increased with increasing nitrogen concentration for all different forms of nitrogen except $\mathrm{NH}_{4} \mathrm{Cl}$. The Scenedesmus obliquus growth was promoted by adding $\mathrm{NaNO}_{3}$ and $\mathrm{CH}_{4} \mathrm{~N}_{2} \mathrm{O}$, but was inhibited by adding $\mathrm{NH}_{4} \mathrm{Cl}$. Adding $2 \mathrm{mg} \mathrm{N} \mathrm{L} \mathrm{N}^{-1}$ of $\mathrm{CH}_{4} \mathrm{~N}_{2} \mathrm{O}$ daily yielded the highest cell density $\left(1.7 \times 10^{7}\right.$ cells $\left.\mathrm{mL}^{-1}\right)$ and lipid production $\left(242.4 \mathrm{mg} \mathrm{L}^{-1}\right)$. These conditions can thus maintain the biomass of Scenedesmus obliquus, increase its lipid accumulation, and decrease the costs of biodiesel production.
\end{abstract}

Keywords: Scenedesmus obliquus; nitrogen forms; supply mode; biodiesel; lipid production; lutein

\section{Introduction}

Microalgae are considered as the potential feedstock for biodiesel production [1], because they have a rapid growth rate [2] and high lipid contents [3]. Scenedesmus obliquus is one of the most widely used lipid-producing microalgae [4,5]. The proportions of C16-C18 and unsaturated fatty acid in the fatty acids produced by Scenedesmus obliquus are both high [6]. These fatty acids are favorable for the synthesis of high-quality biodiesel that exhibits good performance in terms of combustion and low-temperature flow. However, the lipid content of Scenedesmus obliquus under conventional culture conditions is less than 17\% [7]. Microalgae's lipid content plays a decisive role in determining the cost of microalgae-derived biodiesel [8]. Therefore, it is imperative to increase the Scenedesmus obliquus lipid content.

Nitrogen starvation is an effective method to increase the lipid content of microalgae [9]. Pancha et al. [10] found that the lipid content of Scenedesmus sp. CCNM 1077 cultured in a nitrogen-free medium was significantly higher than that cultured in a BG-11 medium. Jia et al. [11] reported that the lipid content of Nannochloropsis oceanica cultured under nitrogen-depleted conditions was approximately twice as large as that observed for a sample cultured in a conventional medium. Converti et al. [12] reported that the lipid contents of Nannochloropsis oculata and Chlorella vulgaris increased from $7.9 \%$ to $15.3 \%$ and from $5.9 \%$ to $16.4 \%$, respectively, when the nitrogen concentration in the medium was decreased by $75 \%$. Lv et al. [13] showed that the total lipid content of Chlorella cells decreased as the nitrogen concentration was increased. More recently, Qi et al. [14] found that the lipid content of Chlorella vulgaris SDEC-3M rapidly increased after the cells were shifted from 
a nitrogen-rich to a nitrogen-deficient broth. Unfortunately, the nitrogen deficiency could lead to an unsatisfactory level of biomass production. Therefore, although microalgae synthesize lipid in nitrogen-free environments, the growth inhibition in algae cells under these conditions results in an overall lower lipid production.

Yu et al. [7] previously employed a two-step cultivation method to promote lipid production by Chlorella and Scenedesmus. In the first step, each microalga was cultured in a culture medium that contained sufficient nitrogen to ensure an optimal level of biomass production. In the second step, the microalga was harvested and transferred into a nitrogen-free culture medium to increase the lipid content. High production costs were observed due to the process for algae and water separation, which prevented the method from being utilized in large-scale biodiesel production [15].

Biomass productivity improvement can be achieved by a fed-batch culture mode. Han et al. [16] showed that adding a limited amount of $\mathrm{NaNO}_{3}$ to the medium daily was beneficial for algae growth and lipid production. Accordingly, it could be possible to simultaneously promote the growth of microalgae and increase the lipid content by adding a limited amount of nitrogen to the medium on a daily basis. Moreover, lutein synthesized by Scenedesmus obliquus can be used as a by-product of lipid production, which could further decrease the costs of lipid production. Sonkar and Mallick [15] found that adding $0.01 \mathrm{~g} \mathrm{~L}^{-1}$ nitrate to the medium at an interval of three days facilitated the biomass production and lipid productivity of Scenedesmus obliquus, Chlorella vulgaris, and Chlorella minutissima. However, they did not study the effects of different nitrogen forms on the growth of microalgae and lipid production. Nitrogen forms have a certain influence on the growth and lipid production of microalgae. Li et al. [17] found that urea was more beneficial to microalgae growth and lipid accumulation compared with nitrate. Amin et al. [18] reported that compared with nitrogen sources such as $\left(\mathrm{NH}_{4}\right)_{2} \mathrm{CO}_{3}, \mathrm{KNO}_{3}, \mathrm{NH}_{4} \mathrm{NO}_{3}$, and $\mathrm{NaNO}_{3}$, Chlorella M2 exhibited the higher biomass and lipid production in the medium with urea as the nitrogen source. Based on the above discussion, it is necessary to understand the effects of nitrogen forms on the growth and lipid production of microalgae.

This study investigated the effects of different nitrogen forms and supply methods on the growth, lipid production, and other major components of Scenedesmus obliquus. It was suggested that adding different forms of nitrogen with multiple small-dose methods could simultaneously promote the growth and lipid production of Scenedesmus obliquus, leading to a lower biodiesel production cost.

\section{Materials and Methods}

\subsection{Alga Strain}

A unicellular strain of Scenedesmus obliquus (FACHB 416) was purchased from the Freshwater Algae Culture Collection of the Institute of Hydrobiology, Chinese Academy of Science, Wuhan, China. The strain in the logarithmic phase was used for inoculation and testing after it was cultured for more than three months in the M-11 medium.

\subsection{Experimental Design}

Experiments were carried out with Scenedesmus obliquus cultured in the M-11 medium and a two-step cultivation method was used as a control test. The novel process involved the daily addition of multiple small-dose nitrogen. For the two-step cultivation method, the first step was to culture the algae in the M-11 medium until the logarithmic phase was reached. The second step was to harvest and transfer the algae into a nitrogen-free $\mathrm{M}-11$ medium for the further cultivation until 20 days. The process of the daily addition of multiple small-doses of nitrogen was described as follows: The Scenedesmus obliquus was firstly cultivated in the nitrogen-free M- 11 medium, $0.5 \mathrm{~mL}$ solution with varying different nitrogen concentrations (the term "nitrogen" in this context is used as catchall for different types of nitrogen containing compounds, including $\mathrm{NaNO}_{3}, \mathrm{NH}_{4} \mathrm{Cl}$, and $\mathrm{CH}_{4} \mathrm{~N}_{2} \mathrm{O}$ ) was added daily. The final nitrogen concentrations for different forms of nitrogen were set to $0.1,0.5,1$, and $2 \mathrm{mg} \mathrm{L}^{-1}$, respectively. Each sample was conducted in triplicate. 


\subsection{Culture Conditions}

The Scenedesmus obliquus strain was inoculated with a density of $10 \times 10^{4}$ cells $\mathrm{mL}^{-1}$ into a $250 \mathrm{~mL}$ conical flasks, which contained a $150 \mathrm{~mL}$ M-11 medium $\left(\mathrm{NaNO}_{3} 100 \mathrm{mg} \mathrm{L}^{-1}, \mathrm{~K}_{2} \mathrm{HPO}_{3} 10 \mathrm{mg} \mathrm{L}^{-1}\right.$, $\mathrm{MgSO}_{4} 75 \mathrm{mg} \mathrm{L}^{-1}, \mathrm{CaCl}_{2} 40 \mathrm{mg} \mathrm{L}{ }^{-1}, \mathrm{Na}_{2} \mathrm{CO}_{3} 20 \mathrm{mg} \mathrm{L}^{-1}$, ferric citrate $6 \mathrm{mg} \mathrm{L}^{-1}$, and $\mathrm{Na}_{2} \mathrm{EDTA}$ $1 \mathrm{mg} \mathrm{L}^{-1} ; \mathrm{pH}$ 8.0). It was then incubated with a temperature of $25^{\circ} \mathrm{C}$, a light intensity of $50 \mu \mathrm{mol}$ photons $\mathrm{m}^{-2} \mathrm{~s}^{-1}$, and a $12 \mathrm{~h}$ light: $12 \mathrm{~h}$ dark photoperiod. The flasks were agitated by hand three times per day.

\subsection{Analytical Methods}

\subsubsection{Analysis of Cell Density}

Cell density was monitored daily by measuring the $\mathrm{OD}_{680}$ value using an ultraviolet-visible spectrophotometer (UV-1780, Shimadzu, Japan) [19]. The linear correlation (Equation 1) between the cell density of Scenedesmus obliquus and $\mathrm{OD}_{680}$ was established for the subsequent Scenedesmus obliquus density determination:

$$
\text { Cell density }\left(10^{4} \text { cells } \mathrm{mL}^{-1}\right)=1037 \mathrm{OD}_{680}+38, \mathrm{R}^{2}=0.999
$$

\subsubsection{Chemical Analysis}

The total dissolved nitrogen (TDN) concentration was determined by potassium peroxodisulfate oxidation-ultraviolet spectrophotometry [20]. Here, $10 \mathrm{~mL}$ of filtrate was added to a $25 \mathrm{~mL}$ colorimetric tube. Then, $5 \mathrm{~mL}$ of alkaline potassium peroxodisulfate was added, a stopper plug was fitted, and the sample was placed in an autoclave where it was heated to $121^{\circ} \mathrm{C}$ and kept for $30 \mathrm{~min}$. After being allowed to cool naturally, $1 \mathrm{~mL}$ of $1 \mathrm{~mol} \mathrm{~L}^{-1}$ hydrochloric acid was added and the sample was diluted to a volume of $25 \mathrm{~mL}$ by adding ammonia-free water. The absorbance at $220 \mathrm{~nm}\left(\mathrm{OD}_{220}\right)$ and $275 \mathrm{~nm}\left(\mathrm{OD}_{275}\right)$ was then measured using ammonia-free water as the blank. This information was then combined with data from the standard TDN curve to obtain the TDN concentration.

The total dissolved phosphorus (TDP) concentration was determined by molybdenum antimony spectrophotometry [20]. Firstly, $25 \mathrm{~mL}$ of the filtrate was pipetted into a $50 \mathrm{~mL}$ colorimetric tube, afterwards, $5 \mathrm{~mL}$ of potassium peroxodisulfate solution was added. The tube was then sealed with a glass stopper and placed in an autoclave where it was heated to $121^{\circ} \mathrm{C}$ and kept for $30 \mathrm{~min}$. After being allowed to cool naturally, $1 \mathrm{~mL}$ of $10 \%$ ascorbic acid was added, followed by adding $2 \mathrm{~mL}$ of molybdate solution $30 \mathrm{~s}$ later. The sample was mixed well and diluted to $50 \mathrm{~mL}$ with distilled water and allowed to stand for $15 \mathrm{~min}$. The sample was finally adjusted to zero at $700 \mathrm{~nm}$ using distilled water. Absorbance was then determined, and TDP concentration was obtained based on the standard TDP curve.

The total organic carbon analyzer (TOC-CPN, Shimadzu, Japan) was used to analyze the dissolved organic carbon (DOC) concentration [19].

\subsubsection{Total Organic Carbon Analysis}

The total organic carbon (TOC) concentration was determined by testing $10 \mathrm{~mL}$ of algae solution using a TOC analyzer (TOC-CPN, Shimadzu, Japan).

\subsubsection{Analysis of Quantum Yield and Lutein}

The maximum quantum yield $\left(F_{v} / F_{m}\right)$ was measured by phytoplankton fluorometry (Aquapen-C) using a sample solution of algae that was placed in dark adaptation conditions for $20 \mathrm{~min}$ [19].

Lutein was extracted by filtering a $5 \mathrm{~mL}$ algae solution with a $47 \mathrm{~mm}$ GF/F filter. The filter membrane was transferred to $25 \mathrm{~mL}$ test tubes and $10 \mathrm{~mL}$ of acetone solution was added before the sample was ultrasonically mixed at $4{ }^{\circ} \mathrm{C}$ for $10 \mathrm{~min}$. The sample was then transferred to dark conditions at $-20^{\circ} \mathrm{C}$ for $24 \mathrm{~h}$. The filtrate extracted with a Teflon syringe filter was placed into a $2 \mathrm{~mL}$ brown 
chromatography bottle for high performance liquid chromatography (1100 Series, Agilent USA) for pigment analysis [21].

\subsubsection{Lipid Content Analysis}

The algae solution was centrifuged at 10,000 $\mathrm{rpm}$ for $6 \mathrm{~min}$ and the algae residue was dried to constant weight at $60{ }^{\circ} \mathrm{C}$ to collect dry algae. The lipid was extracted using the methanol-chloroform method described by Gan [20].

Then, $100 \mathrm{mg}$ of dried algae was precisely measured and transferred $\left(\mathrm{W}_{\mathrm{a}}\right)$ into a $50 \mathrm{~mL}$ centrifuge tube. Afterwards, $12 \mathrm{~mL}$ of 1:2 chloroform-methanol solution was added. The tube was centrifuged at $25^{\circ} \mathrm{C}$ for $60 \mathrm{~min}$ and then centrifuged at $10,000 \mathrm{rpm}$ for $6 \mathrm{~min}$. After filtering through a $0.45 \mu \mathrm{m}$ filter membrane (Whatman \# 1), the filtrate was transferred into a clean tube. The above extraction process was repeated again, and the two filtrates were combined. The combined filtrate was thoroughly mixed with $16 \mathrm{~mL}$ of $5 \% \mathrm{NaCl}$. The liquid in the lower layer was separated and concentrated with a rotary evaporator (RE-2000A, Yarong Biochemical Instrument Company, Shanghai, China), then transferred into a $4 \mathrm{~mL}$ vial $\left(\mathrm{W}_{\mathrm{i}}\right)$. The vial was dried using a nitrogen purging instrument (ND200-1, Hang Zhou Rui Cheng Instrument Co., Ltd., Hang Zhou, China) at $45^{\circ} \mathrm{C}$ until the sample reached a constant mass $\left(\mathrm{W}_{\mathrm{f}}\right)$. Equation (2) and Equation (3) were used to calculate the lipid content and lipid production, respectively.

$$
\begin{gathered}
\text { Lipid content }(\%)=\left(\mathrm{W}_{\mathrm{f}}-\mathrm{W}_{\mathrm{i}}\right) / \mathrm{W}_{\mathrm{a}} \times 100 \\
\text { Lipid production }\left(\mathrm{mg} \mathrm{L}^{-1}\right)=\text { Lipid content }(\%) \times \text { Dry mass }\left(\mathrm{mg} \mathrm{L}^{-1}\right)
\end{gathered}
$$

\subsubsection{Fatty acid Composition Analysis}

Fatty acid methyl esters (FAMEs) were analyzed according to the method described by Peng [5]. The extracted dry lipid was completely dissolved by $4 \mathrm{~mL}$ of $14 \% \mathrm{BF}_{3}-$ methanol and then kept in a boiled water bath for $15 \mathrm{~min}$. After cooling, $2 \mathrm{~mL}$ of $n$-heptane and $4 \mathrm{~mL}$ of saturated $\mathrm{NaCl}$ solution were added and the mixture was shaken intensively. After stratification, the supernatant was filtered using a $0.22 \mu \mathrm{m}$ organic phase needle filter (TPFM012, Nan Jing Tai Pu Rui Instrument Equipment Co., Ltd., Nan Jing, China). FAMEs were analyzed using a gas chromatograph (GC-2014C, Shimadzu, Japan) equipped with Flame Ionization Detector (FID) and a DB-5 ms (60 m) capillary column. The carrier gas was $\mathrm{N}_{2}$ and the injection and detector temperatures were 250 and $290{ }^{\circ} \mathrm{C}$, respectively. The initial column temperature was kept at $120^{\circ} \mathrm{C}$ for $3 \mathrm{~min}$. It was then increased to $220^{\circ} \mathrm{C}$ at the rate of $4{ }^{\circ} \mathrm{C}$ $\mathrm{min}^{-1}$ and kept for $5 \mathrm{~min}$. The final temperature was increased to $280^{\circ} \mathrm{C}$ at the rate of $3^{\circ} \mathrm{C} \mathrm{min}^{-1}$ and kept for $20 \mathrm{~min}$. The injection volume was $1 \mu \mathrm{L}$.

\subsection{Statistics}

All data in this study were presented as the mean value \pm the standard deviation, and data processing and mapping were performed using Microsoft Excel 2010. Significant differences were determined by the analysis of variance (ANOVA) using the Tukey post-hoc test in SPSS 19.0. Significant levels were recorded at $p<0.05$.

\section{Results and Discussion}

\subsection{Growth of S. obliquus}

Figure 1 showed the growth curves of Scenedesmus obliquus under different culture modes. Results for the first step of the two-step cultivation method (the first nine days) were basically consistent with the growth trend of Scenedesmus obliquus in the M-11 medium. However, in the second step, the growth rate of Scenedesmus obliquus obviously slowed. On the 20th day, the biomass was recorded at $6.3 \times 10^{6}$ cells $\mathrm{mL}^{-1}$, which was significantly lower than the $1.0 \times 10^{7}$ cells $\mathrm{mL}^{-1}$ observed in the M-11 medium (Figure 1a). Sonkar and Mallick [15] demonstrated a similar trend that the biomass 
concentration of Scenedesmus obliquus with a limited $\mathrm{KNO}_{3}$ feed was $27 \%$ higher than the two-step cultivation method. Under the condition that different nitrogen sources were added to the nitrogen-free medium every day, the algae density increased with increasing nitrogen concentration in the same form of nitrogen source (Figure $1 \mathrm{~b}-\mathrm{d}$ ). Another study identified the similar trend of $\mathrm{NaNO}_{3}$ and $\mathrm{CH}_{4} \mathrm{~N}_{2} \mathrm{O}$ that high nitrogen concentration could promote the algae biomass [17]. Compared to cultivation in the M-11 medium, the daily addition of $\mathrm{NH}_{4} \mathrm{Cl}$ inhibited Scenedesmus obliquus growth, while the Scenedesmus obliquus growth has been promoted only in the conditions where $2 \mathrm{mg} \mathrm{L}^{-1}$ nitrogen of $\mathrm{NaNO}_{3}$ or $\mathrm{CH}_{4} \mathrm{~N}_{2} \mathrm{O}$ was added. The largest algae density $\left(1.7 \times 10^{7}\right.$ cells $\left.\mathrm{mL}^{-1}\right)$ was recorded with the addition of $2 \mathrm{mg} \mathrm{N} \mathrm{L}^{-1}$ of $\mathrm{CH}_{4} \mathrm{~N}_{2} \mathrm{O}$. Li et al. [17] found that the microalgae were able to utilize $\mathrm{CH}_{4} \mathrm{~N}_{2} \mathrm{O}$ as a nitrogen source for growth compared to $\mathrm{NaNO}_{3}$, and the biomass of Chlorococcum ellipsoideum were the largest with $246 \mathrm{mg} \mathrm{N} \mathrm{L}^{-1}$ of $\mathrm{CH}_{4} \mathrm{~N}_{2} \mathrm{O}$. This similar result indicated that $\mathrm{CH}_{4} \mathrm{~N}_{2} \mathrm{O}$ was better than $\mathrm{NaNO}_{3}$ for microalgae growth.
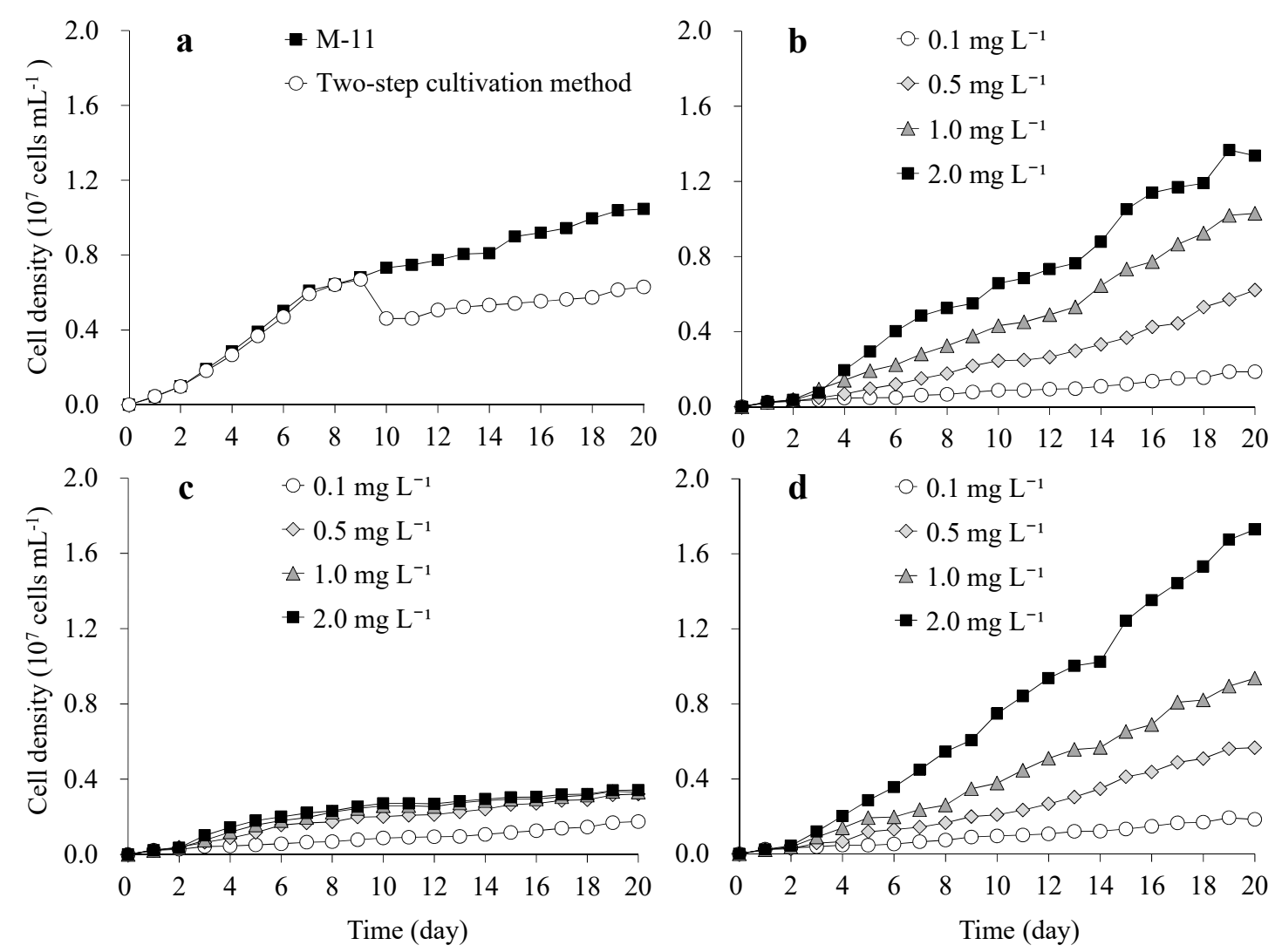

Figure 1. Growth curves of Scenedesmus obliquus under different treatments: M-11 medium and two-step cultivation method (a); and with daily additions of various concentrations of $\mathrm{NaNO}_{3}(\mathbf{b}) ; \mathrm{NH}_{4} \mathrm{Cl}(\mathbf{c})$; and $\mathrm{CH}_{4} \mathrm{~N}_{2} \mathrm{O}(\mathbf{d})$.

\subsection{TDN, TDP, and DOC Concentrations in Medium Filtrate}

The microalgae lipid content was also determined by the nutrient concentration in the culture medium. The final concentrations of TDN, TDP, and DOC following the different treatments were shown in Figure 2. The maximum filtrate TDN concentration $\left(19.6 \mu \mathrm{g} \mathrm{mL}^{-1}\right)$ was obtained following the daily addition of $2 \mathrm{mg} \mathrm{N} \mathrm{L}^{-1}$ of $\mathrm{NH}_{4} \mathrm{Cl}$ (Figure 2a). This value was significantly higher than that of the control $\left(1.5 \mu \mathrm{g} \mathrm{mL}^{-1}\right)$ and that of the two-step cultivation method $\left(1.3 \mu \mathrm{g} \mathrm{mL}^{-1}\right)(p<0.05)$. There were no significant differences in TDN concentrations among the three nitrogen source treatments at nitrogen concentrations of $0.1,0.5$, and $1 \mathrm{mg} \mathrm{N} \mathrm{L}^{-1}$ (except for $1 \mathrm{mg} \mathrm{N} \mathrm{L}^{-1} \mathrm{NH}_{4} \mathrm{Cl}$ ). Among the three nitrogen source treatments with a concentration of $2 \mathrm{mg} \mathrm{N} \mathrm{L}^{-1}$, the lowest concentration of TDN was $5.644 \mu \mathrm{g} \mathrm{mL}^{-1}$ when $2 \mathrm{mg} \mathrm{N} \mathrm{L}^{-1}$ of $\mathrm{CH}_{4} \mathrm{~N}_{2} \mathrm{O}$ was added, which indicated that the addition 
of $2 \mathrm{mg} \mathrm{N} \mathrm{L}^{-1} \mathrm{CH}_{4} \mathrm{~N}_{2} \mathrm{O}$ could promote the nitrogen uptake of Scenedesmus obliquus. However, the addition of $2 \mathrm{mg} \mathrm{N} \mathrm{L}^{-1} \mathrm{NH}_{4} \mathrm{Cl}$ was not conducive to the absorption of Scenedesmus obliquus.
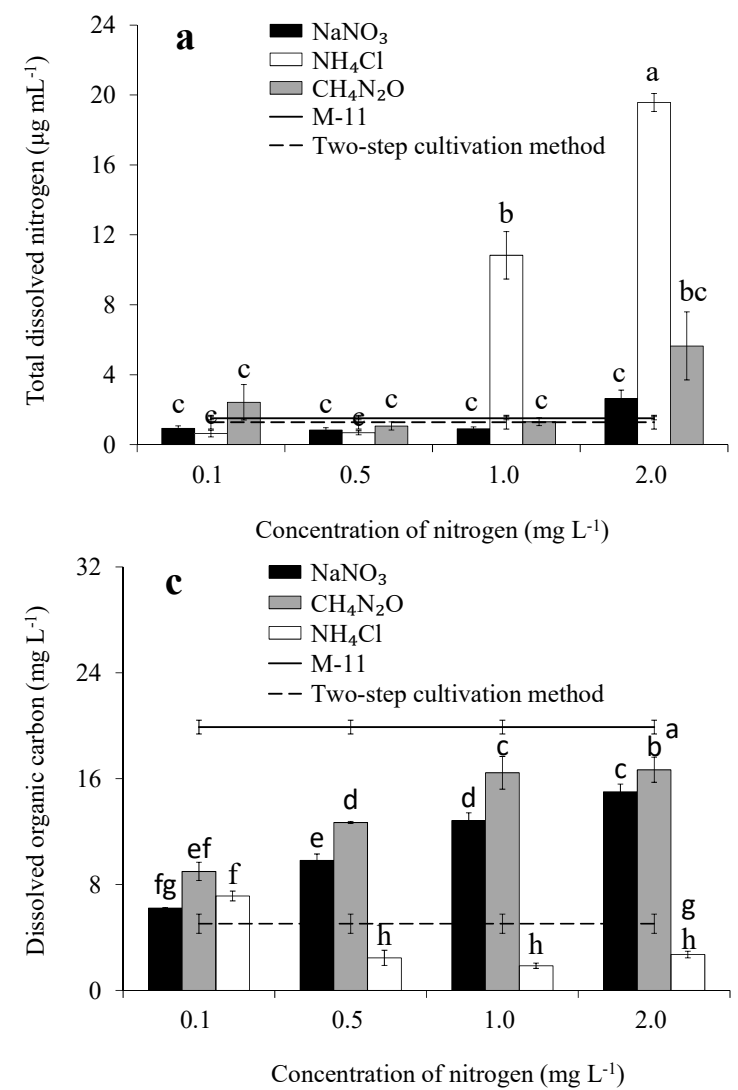

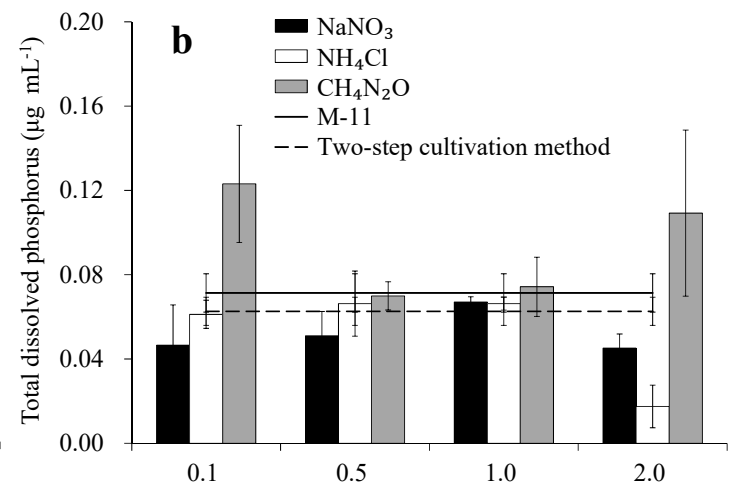

Concentration of nitrogen $\left(\mathrm{mg} \mathrm{L}^{-1}\right)$

Figure 2. Final concentrations of total dissolved nitrogen (a); total dissolved phosphorus (b); and dissolved organic carbon (c) under different treatments. Lowercase letters indicate significant differences among treatments $(p<0.05)$.

TDP concentrations in the samples treated with $\mathrm{NaNO}_{3}$ and $\mathrm{NH}_{4} \mathrm{Cl}$ initially increased with increasing nitrogen concentration, but decreased when $2 \mathrm{mg} \mathrm{L}^{-1}$ of nitrogen was added. Conversely, the concentration of TDP in samples treated with $\mathrm{CH}_{4} \mathrm{~N}_{2} \mathrm{O}$ firstly declined as a function of nitrogen concentration, then increased when the nitrogen concentration was higher than $1 \mathrm{mg} \mathrm{L}^{-1}$ (Figure $2 \mathrm{~b}$ ). The maximum filtrate TDP concentration was $0.1 \mu \mathrm{g} \mathrm{mL} \mathrm{L}^{-1}$ for the medium treated with $0.1 \mathrm{mg} \mathrm{N} \mathrm{L}^{-1}$ of $\mathrm{CH}_{4} \mathrm{~N}_{2} \mathrm{O}$ and no significant difference $(p>0.05)$ in TDP concentration among all treatments, which is similar to the conclusion of $\mathrm{Li}$ [22] that $83-99 \%$ of nitrogen and $99 \%$ of phosphorus in the medium can be absorbed, and the lipid accumulation increased when the nutrition was relatively lacking. The filtrate DOC concentration increased with the nitrogen concentration during the addition of $\mathrm{NaNO}_{3}$ and $\mathrm{CH}_{4} \mathrm{~N}_{2} \mathrm{O}$. Conversely, the filtrate $\mathrm{DOC}$ concentration following the addition of $\mathrm{NH}_{4} \mathrm{Cl}$ decreased with increasing nitrogen concentration (Figure 2c). The maximum DOC concentration in the control sample was $19.9 \mathrm{mg} \mathrm{L}^{-1}$, which was significantly higher than that observed for the various nitrogenated media $(p<0.05)$.

\subsection{Total Organic Carbon Concentration, and Content}

The concentration of TOC in Scenedesmus obliquus increased as the added nitrogen concentration was increased (Figure 3a). The highest TOC concentration among the control samples was $458.2 \mathrm{mg} \mathrm{L}^{-1}$, which was significantly higher than that in the two-step cultivation method $\left(190.6 \mathrm{mg} \mathrm{L}^{-1}\right)(p<0.05)$. Scenedesmus obliquus absorbs organic carbon in the culture medium and converts it into lipid [23]. The TOC content of each cell decreased with increasing nitrogen concentration in the $\mathrm{NH}_{4} \mathrm{Cl}$ and 
$\mathrm{CH}_{4} \mathrm{~N}_{2} \mathrm{O}$ media (Figure 3b). This showed that Scenedesmus obliquus converted the absorbed organic carbon into lipid to conserve energy.
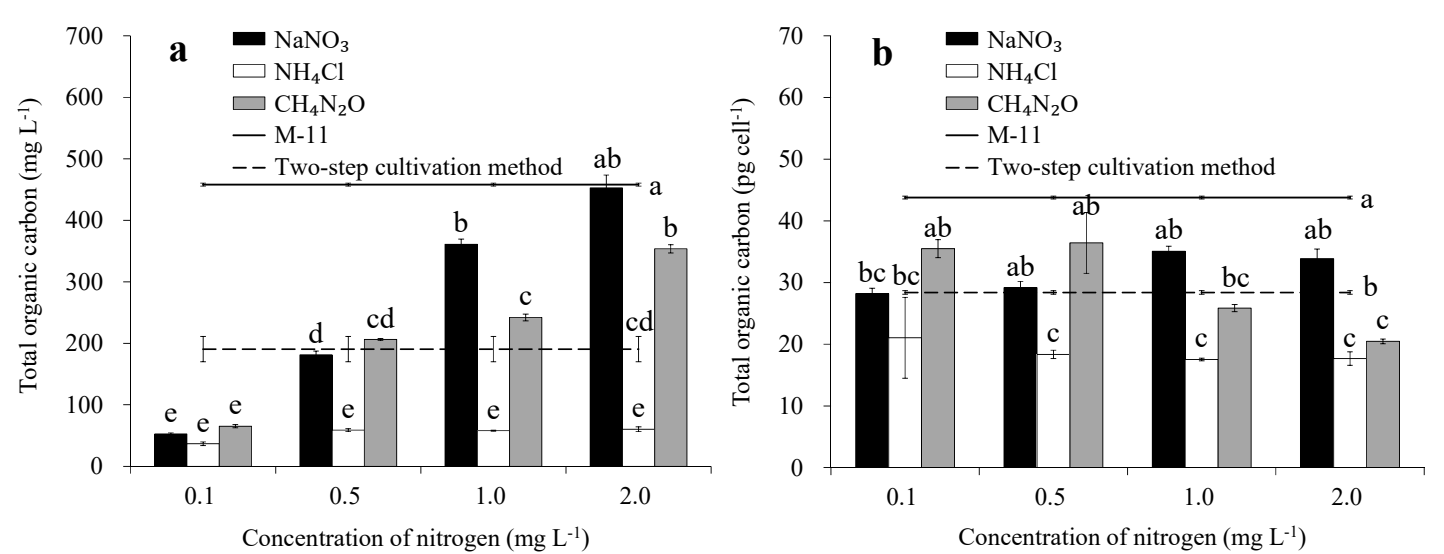

Figure 3. Total organic carbon concentration (a) and total organic carbon content (b) of Scenedesmus obliquus following different treatments. Lowercase letters indicate significant differences among treatments $(p<0.05)$.

\subsection{Chlorophyll Fluorescence}

From the perspective of photosynthetic efficiency of algae cells, the $F_{\mathrm{v}} / F_{\mathrm{m}}$ value indicates the maximum photochemical efficiency of PS II. This value reflects the photosynthetic efficiency of algae cells, and is an indicator of the toxicity degree of the stress environment to algae cells. In general, the $F_{\mathrm{v}} / F_{\mathrm{m}}$ values of algae cells remain constant under favorable environmental conditions, but significantly decrease in algae cells under stress conditions [24]. In the current study, the value of $F_{\mathrm{v}} / F_{\mathrm{m}}$ gradually increased when the concentration of different forms of nitrogen added daily was increased from 0.1 to $0.5 \mathrm{mg} \mathrm{L}^{-1}$ (Figure 4 ). The $F_{\mathrm{v}} / F_{\mathrm{m}}$ of Scenedesmus obliquus remained constant with $\mathrm{NaNO}_{3}$ and $\mathrm{CH}_{4} \mathrm{~N}_{2} \mathrm{O}$ treatments, but showed the downward trend in $\mathrm{NH}_{4} \mathrm{Cl}$ treatments when the nitrogen concentration was further increased from 0.5 to $2 \mathrm{mg} \mathrm{L}^{-1}$. These results indicated that the addition of $\mathrm{NaNO}_{3}$ and $\mathrm{CH}_{4} \mathrm{~N}_{2} \mathrm{O}$ treatments could provide favorable conditions for Scenedesmus obliquus, allowing improvement in its photosynthetic efficiency. The maximum $F_{\mathrm{v}} / F_{\mathrm{m}}$ value of 0.6 was observed in the treatment with $0.5 \mathrm{mg} \mathrm{N} \mathrm{L}^{-1}$ of $\mathrm{CH}_{4} \mathrm{~N}_{2} \mathrm{O}$ addition. Among the three nitrogen sources in our study, adding $2 \mathrm{mg} \mathrm{N} \mathrm{L}^{-1}$ of $\mathrm{CH}_{4} \mathrm{~N}_{2} \mathrm{O}$ resulted in a high $F_{\mathrm{v}} / F_{\mathrm{m}}$ of Scenedesmus obliquus, which could promote the growth of Scenedesmus obliquus.

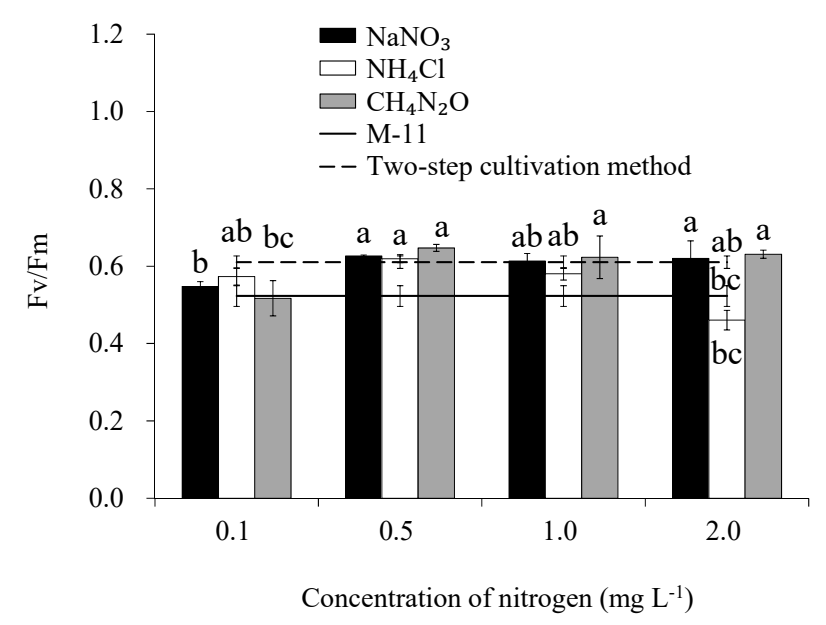

Figure 4. $F_{\mathrm{v}} / F_{\mathrm{m}}$ values of Scenedesmus obliquus following different treatments. Lowercase letters indicate significant differences among treatments $(p<0.05)$. 


\subsection{Lipid Content, Production, and Productivity}

The lipid content firstly decreased and then increased with increasing nitrogen concentration for the treatments where $\mathrm{NaNO}_{3}$ and $\mathrm{NH}_{4} \mathrm{Cl}$ were added daily. The highest lipid content of $30.6 \%$ was observed when $0.1 \mathrm{mg} \mathrm{N} \mathrm{L}^{-1}$ of $\mathrm{NH}_{4} \mathrm{Cl}$ was added (Figure 5a). Lipid production increased with increasing nitrogen concentration for each form of nitrogen (Figure 5b). The addition of $2 \mathrm{mg} \mathrm{N} \mathrm{L}^{-1}$ of $\mathrm{CH}_{4} \mathrm{~N}_{2} \mathrm{O}$ resulted in the highest lipid production $\left(242.4 \mathrm{mg} \mathrm{L}^{-1}\right)$, which was significantly higher than the control sample $\left(87.9 \mathrm{mg} \mathrm{L}^{-1}\right)$ and that observed for the two-step cultivation method $\left(91.8 \mathrm{mg} \mathrm{L}^{-1}\right)$ $(p<0.05)$.
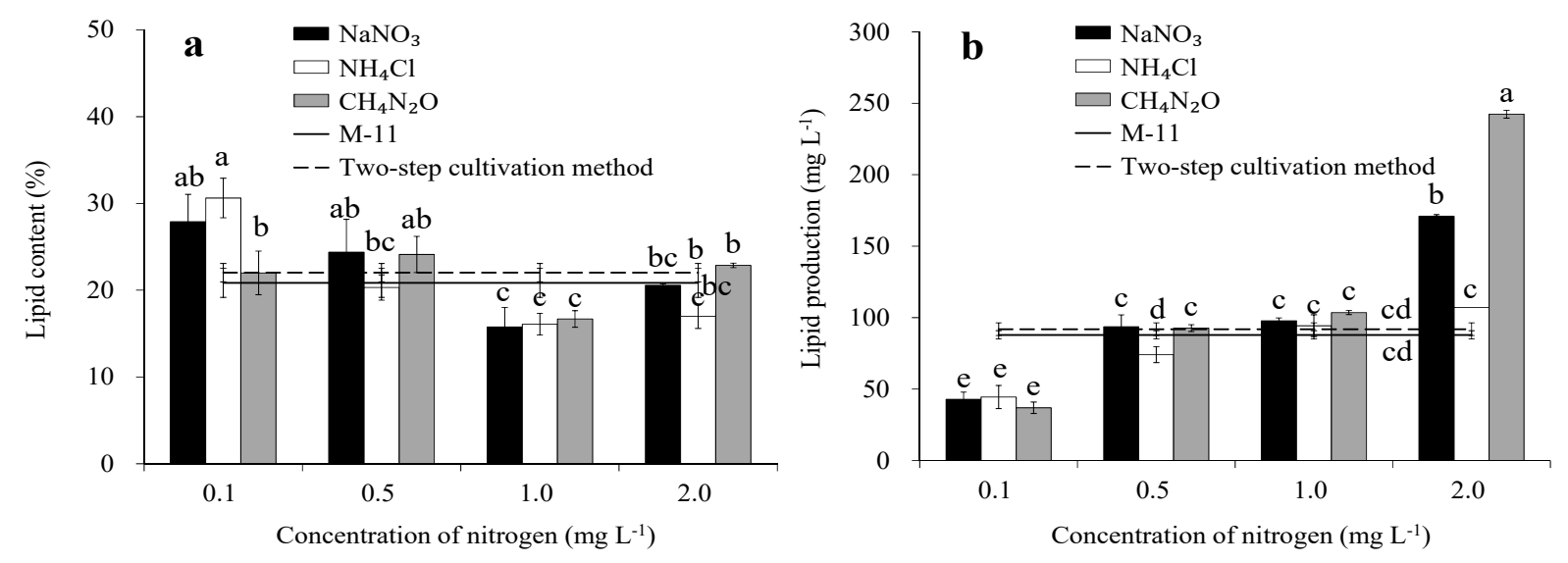

Figure 5. Lipid content (a) and lipid production (b) of Scenedesmus obliquus under different treatments. Lowercase letters indicate significant differences among treatments $(p<0.05)$.

The above results showed that adding $2 \mathrm{mg} \mathrm{N} \mathrm{L}^{-1}$ of $\mathrm{CH}_{4} \mathrm{~N}_{2} \mathrm{O}$ every day yielded the highest lipid productivity $\left(12.1 \mathrm{mg} \mathrm{L}^{-1} \mathrm{day}^{-1}\right)$, and this value was significantly higher than those found for the other treatments. Reported values of lipid productivity of Scenedesmus obliquus under different non-aerated culturing processes were shown in Table 1. Li et al. [22] reported that the lipid productivity of Scenedesmus LX1 was $11.6 \mathrm{mg} \mathrm{L}^{-1}$ day $^{-1}$ when the nitrogen content in the medium was $10 \mathrm{mg} \mathrm{L}^{-1}$. Yu et al. [25] noted a lipid productivity of $11.9 \mathrm{mg} \mathrm{L}^{-1}$ day $^{-1}$ when $5 \mathrm{mg} \mathrm{L}^{-1}$ auxin was added to the BG-11 medium when undergoing the two-step cultivation method. Compared to the data in Table 1, it can be suggested that multiple small-doses of nitrogen can increase lipid productivity.

The nitrogen concentration directly affects the composition of macromolecular organic matter in microalgae cells. Some studies $[7,10,28]$ have found that microalgae could preferentially synthesize lipid to store energy when they were starved of nitrogen. Conversely, Long et al. [29] found that Microcystis aeruginosa preferentially synthesizes proteins when the concentration of nitrogen was increased. It can be inferred that the lipid content of Scenedesmus obliquus would decrease when the nitrogen concentration was increased, which is due to the transformation of organic matter into protein. This trend was consistent with the observed results.

Although a higher nitrogen concentration may decrease the lipid content, this study showed that lipid production significantly increased when culturing with multiple small doses of nitrogen. Li et al. [22] found that lipid content decreased but lipid production increased with increasing nitrogen concentration under nitrogen-starvation conditions. These results can be explained by the fact that the total amount of lipid accumulation is determined by the accumulation rate of organic matter under photosynthesis, algae respiration, the composition of organic matter, and the transformation mechanism of organic matter to different macromolecular organic substances such as lipids, polysaccharides, and proteins. The TOC and biomass content of Scenedesmus obliquus increased when the nitrogen concentration was increased for different forms of nitrogen. This indicated that the increased nitrogen concentration was beneficial to the synthesis of organic matter and can increase the biomass of Scenedesmus obliquus with the treatment of multiple small doses of nitrogen. In this study, the increase 
in biomass directly led to the increase in lipid production. Adding $2 \mathrm{mg} \mathrm{N} \mathrm{L}^{-1}$ of $\mathrm{CH}_{4} \mathrm{~N}_{2} \mathrm{O}$ every day increased the organic matter accumulation rate of Scenedesmus obliquus and yielded the highest lipid production $\left(242.4 \mathrm{mg} \mathrm{L}^{-1}\right)$ of all treatments. It suggested that this culturing process can effectively improve the lipid productivity of Scenedesmus obliquus.

Table 1. Lipid productivity for various microalgae species grown under different culture conditions without aeration.

\begin{tabular}{|c|c|c|c|c|}
\hline Algae Strain & Treatment & $\begin{array}{l}\text { Lipid } \\
\text { Content } \\
(\%)\end{array}$ & $\begin{array}{l}\text { Lipid Productivity } \\
\left(\mathrm{mg} \mathrm{L}^{-1} \text { day }^{-1}\right)\end{array}$ & References \\
\hline \multirow{3}{*}{$\begin{array}{l}\text { Scenedesmus obliquus } \\
\text { FACHB-416 }\end{array}$} & $\mathrm{BG}-11+1.2 \mathrm{~g} \mathrm{~L}^{-1} \mathrm{NaCl}$ & 16.2 & 9.9 & \multirow{3}{*}{ Gan et al. [20] } \\
\hline & $\mathrm{BG}-11+8.8 \mathrm{~g} \mathrm{~L}^{-1} \mathrm{NaCl}$ & 20.8 & 1.8 & \\
\hline & $\mathrm{mBG}-11+2.5 \mathrm{mg} \mathrm{N} \mathrm{L}^{-1}$ of $\mathrm{NaNO}_{3}$ & 29.7 & 8.7 & \\
\hline \multirow[t]{3}{*}{ Scenedesmus sp. LX1 } & $\mathrm{mBG}-11+5 \mathrm{mg} \mathrm{N} \mathrm{L}^{-1}$ of $\mathrm{NaNO}_{3}$ & 22.5 & 8.5 & \multirow[t]{3}{*}{ Li et al. [22] } \\
\hline & $\mathrm{mBG}-11+10 \mathrm{mg} \mathrm{N} \mathrm{L}-1$ of $\mathrm{NaNO}_{3}$ & 20.8 & 11.6 & \\
\hline & $\begin{array}{l}\text { BG-11 + two-step } \\
\text { cultivation method }\end{array}$ & 18.9 & 3.8 & \\
\hline \multirow[t]{3}{*}{ Scenedesmus sp. SDEC-8 } & $\begin{array}{l}\text { BG-11 + two-step cultivation } \\
\text { method }+5 \mathrm{mg} \mathrm{L}^{-1} \text { auxin }\end{array}$ & 46.9 & 11.9 & \multirow[t]{3}{*}{ Yu et al. [25] } \\
\hline & $\begin{array}{l}\text { BG-11 + two-step cultivation } \\
\text { method }+30 \mathrm{mg} \mathrm{L}^{-1} \text { auxin }\end{array}$ & 16.7 & 5.2 & \\
\hline & $\begin{array}{l}\text { BG-11 + two-step cultivation } \\
\text { method }+50 \mathrm{mg} \mathrm{L}^{-1} \text { auxin }\end{array}$ & 14.7 & 2.3 & \\
\hline \multirow{3}{*}{$\begin{array}{l}\text { Scenedesmus obliquus } \\
\text { GU732418 }\end{array}$} & BBM & - & 2.3 & \multirow{3}{*}{ Salama et al. [26] } \\
\hline & $\mathrm{BBM}+1.75 \mathrm{mg} \mathrm{L}^{-1} \mathrm{IAA}$ & - & 4.6 & \\
\hline & $\mathrm{BBM}+2.15 \mathrm{mg} \mathrm{L}^{-1} \mathrm{DAH}$ & - & 5.8 & \\
\hline Dunaliella salina & ESM & - & 0.8 & \multirow{2}{*}{ Kichul et al. [27] } \\
\hline CCAP $19 / 20$ & $\mathrm{ESM}+500 \mathrm{mg} \mathrm{L}^{-1}$ myo-inositol & - & 0.9 & \\
\hline $\begin{array}{l}\text { Scenedesmus obliqquus } \\
\text { FACHB- } 416\end{array}$ & $\begin{array}{l}\text { multiple-dose of } 2 \mathrm{mg} \mathrm{N} \mathrm{L}^{-1} \text { of } \\
\qquad \mathrm{CH}_{4} \mathrm{~N}_{2} \mathrm{O}\end{array}$ & 22.9 & 12.1 & Current study \\
\hline
\end{tabular}

The form of nitrogen can also affect the macromolecular composition of algae organisms. $\mathrm{Qu}$ et al. [30] found that the extracellular polysaccharide content of Microcystis aeruginosa grown in an ammonium culture was higher than that grown in nitrate and urea media. Rückert and Giani [31] found that Microcystis aeruginosa had higher protein content when grown in a nitrate medium than in an ammonium medium. Kamyab et al. [32] reported that $1.5 \mathrm{M}$ of $\mathrm{NH}_{4} \mathrm{NO}_{3}$ concentration produced higher lipid content compared to the same nitrogen concentration which included $\mathrm{NaNO}_{3}$. The above studies showed that the form of nitrogen played an important role in the algae synthesis of organic matter.

Algae convert nitrate to ammonium by using nitrate reductase when absorbing and utilizing nitrates, which consumes energy. A high concentration of ammonium ions can be toxic to algae [33], directly affecting their physiological state and composition. Qu et al. [30] showed that energy consumption by nitrate reductase decreased the amount of extracellular polysaccharides. In the current study, the lipid content was basically the same for all treatments where different forms of nitrogen were added at $1 \mathrm{mg} \mathrm{N} \mathrm{L}^{-1}$, because the growth of Scenedesmus obliquus was limited by the low nitrogen concentration. Lipid production by Scenedesmus obliquus treated with $2 \mathrm{mg} \mathrm{N} \mathrm{L}^{-1}$ of $\mathrm{CH}_{4} \mathrm{~N}_{2} \mathrm{O}$ was significantly higher than that treated with $\mathrm{NaNO}_{3}$ and $\mathrm{NH}_{4} \mathrm{Cl}$. This is due to the fact that during treatment with $\mathrm{NaNO}_{3}$, Scenedesmus obliquus convert nitrate to ammonium. The process consumed a substantial amount of energy and led to an increase in the ammonium ions concentration. Moreover, the increase in the ammonium ion concentration directly affects lipid synthesis. For $\mathrm{NH}_{4} \mathrm{Cl}$, a high concentration of ammonium ions was toxic to algae cells, and thus, not conducive to lipid synthesis. Therefore, for a given concentration, treatment with $\mathrm{CH}_{4} \mathrm{~N}_{2} \mathrm{O}$ was most beneficial to the synthesis of lipids by Scenedesmus obliquus.

Li et al. [22] found that the lipid productivity of Scenedesmus sp. LX1 increased from $8.5 \mathrm{mg} \mathrm{L}^{-1}$ day $^{-1}$ without aeration to $134 \mathrm{mg} \mathrm{L}^{-1}$ day $^{-1}$ after aeration under nitrogen-limited conditions. Rodolfi et al. [34] also showed that the lipid content of Nannochloropsis sp. F\&M-M26 nearly doubled following aeration. 
Babu et al. [35] found that adding $10^{-5}$ mol L ${ }^{-1}$ of indole-3-acetic and $10^{-9} \mathrm{~mol} \mathrm{~L}^{-1}$ of DA-6 increased the lipid productivity of Chlorella by $49 \%$ and $84 \%$, respectively. Yu et al. [7] also showed that the lipid productivity of Scenedesmus SDEC-8 tripled after auxin was added. Therefore, further decrease in biodiesel production cost could be realized by improving the lipid productivity of Scenedesmus obliquus using aeration and phytohormones addition.

\subsection{The Concentration of Lutein in Scenedesmus obliquus}

The highest lutein concentration of Scenedesmus obliquus was $11.3 \mathrm{mg} \mathrm{L}^{-1}$ following the daily addition of $1 \mathrm{mg} \mathrm{N} \mathrm{L}^{-1}$ of $\mathrm{CH}_{4} \mathrm{~N}_{2} \mathrm{O}$ (Figure 6). For the different treatments with $\mathrm{NaNO}_{3}, \mathrm{NH}_{4} \mathrm{Cl}_{\text {, }}$ and $\mathrm{CH}_{4} \mathrm{~N}_{2} \mathrm{O}$, the lutein concentration firstly increased with increasing nitrogen concentration, and it reached the maximum value when $1 \mathrm{mg} \mathrm{N} \mathrm{L}^{-1}$ was added, afterwards, it decreased as a function of nitrogen concentration. Overall, the different nitrogen forms appeared to have little impact on the lutein content.

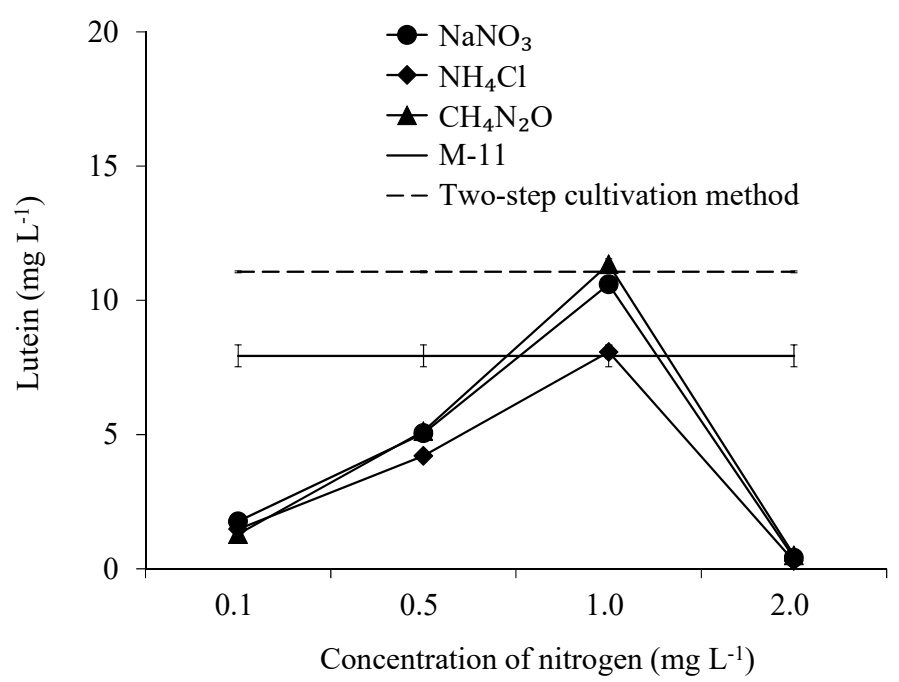

Figure 6. Lutein concentrations of Scenedesmus obliquus under different treatments.

The pigment lutein is a valuable byproduct of lipid production that can effectively decrease the lipid production cost. Lutein is rich in microalgae cells and is the main pigment in the macular area of the human eye where it protects the retina from near-ultraviolet light and decreases the incidence of diseases in the eyes, and delays their ageing and degeneration.

Del Campo et al. [36] reported that the lutein content doubled (reaching $23 \mathrm{mg} \mathrm{L}^{-1}$ ) when the nitrogen concentration in the medium was increased from 140 to $280 \mathrm{mg} \mathrm{L}^{-1}$, but it did not increase further as the nitrogen concentration was increased. Similar to the results presented in the current work, Del Campo et al. [37] found that the lutein content of Chlorella firstly increased and then decreased as the nitrogen concentration was increased from 70 to $560 \mathrm{mg} \mathrm{L}^{-1}$. However, in the current work the lutein content of Scenedesmus obliquus was only $0.5 \mathrm{mg} \mathrm{L}^{-1}$ following treatment with $2 \mathrm{mg} \mathrm{N} \mathrm{L}^{-1}$ of $\mathrm{CH}_{4} \mathrm{~N}_{2} \mathrm{O}$ (the highest lipid production), which was much lower than the values reported above. Changing the form of nitrogen $\left(\mathrm{NaNO}_{3}, \mathrm{NH}_{4} \mathrm{Cl}\right.$, or $\left.\mathrm{CH}_{4} \mathrm{~N}_{2} \mathrm{O}\right)$ employed did not affect the lutein content of Scenedesmus obliquus.

\subsection{Fatty Acid Composition Analysis}

The composition of fatty acids extracted from Scenedesmus obliquus was shown in Table 2. C16:0 (palmitic acid) and C18:1 (oleic acid) were the main components, being ideal for biodiesel production [38]. The highest proportion of C18:1 (55.8\%) was observed following treatment with $0.1 \mathrm{mg} \mathrm{N} \mathrm{L}^{-1} \mathrm{of} \mathrm{NaNO}_{3}$. The largest proportion of C16-C18 fatty acids was $98.2 \%$ and the largest proportion of unsaturated fatty acids was $66.7 \%$. 
Table 2. Fatty acid composition (\%) of Scenedesmus obliquus treated with different culture conditions.

\begin{tabular}{|c|c|c|c|c|c|c|c|c|c|c|c|c|c|c|}
\hline \multirow{2}{*}{ Fatty Acid } & \multirow{2}{*}{ M-11 - } & \multicolumn{4}{|c|}{$\mathrm{NaNO}^{3}$} & \multicolumn{4}{|c|}{$\mathrm{NH}^{4} \mathrm{Cl}$} & \multicolumn{4}{|c|}{$\mathrm{CH}^{4} \mathrm{~N}^{2} \mathrm{O}$} & \multirow{2}{*}{$\begin{array}{c}\text { Two-Step Cultivation } \\
\text { Method }\end{array}$} \\
\hline & & 0.1 & 0.5 & 1 & 2 & 0.1 & 0.5 & 1 & 2 & 0.1 & 0.5 & 1 & 2 & \\
\hline C14:0 & 0.3 & 0.2 & 0.0 & 0.0 & 0.6 & 0.2 & 0.0 & 0.0 & 1.0 & 0.0 & 0.2 & 0.0 & 0.4 & 0.5 \\
\hline C15:0 & 0.6 & 0.3 & 0.4 & 0.5 & 0.5 & 0.3 & 1.7 & 1.0 & 0.9 & 0.3 & 0.4 & 0.6 & 0.9 & 0.6 \\
\hline C16:0 & 31.7 & 29.5 & 30.5 & 34.4 & 51.9 & 32.3 & 53.1 & 47.4 & 51.2 & 30.8 & 31.6 & 40.7 & 34.0 & 58.0 \\
\hline C16:1 & 0.8 & 0.6 & 1.0 & 0.6 & 0.7 & 0.5 & 1.0 & 1.4 & 1.0 & 0.5 & 0.6 & 0.8 & 1.0 & 0.8 \\
\hline C18:0 & 3.3 & 2.8 & 2.7 & 2.7 & 4.7 & 3.0 & 5.0 & 4.3 & 5.3 & 3.1 & 2.5 & 3.6 & 2.8 & 5.2 \\
\hline C18:1 & 52.7 & 55.8 & 54.4 & 49.4 & 28.0 & 53.6 & 25.4 & 32.0 & 17.6 & 55.5 & 53.6 & 40.9 & 46.3 & 24.6 \\
\hline C18:2 & 8.4 & 9.2 & 8.9 & 9.5 & 10.5 & 8.3 & 9.2 & 9.6 & 19.1 & 8.0 & 8.8 & 9.4 & 10.2 & 7.2 \\
\hline C18:3 & 0.4 & 0.3 & 0.3 & 0.6 & 0.8 & 0.3 & 0.9 & 1.1 & 0.8 & 0.1 & 0.3 & 0.8 & 1.0 & 0.7 \\
\hline C20:1 & 0.7 & 0.8 & 0.8 & 0.6 & 0.0 & 0.8 & 0.0 & 0.0 & 0.0 & 0.9 & 0.7 & 0.7 & 0.4 & 0.7 \\
\hline C22:0 & 0.5 & 0.3 & 0.4 & 0.6 & 0.9 & 0.4 & 1.3 & 1.5 & 1.7 & 0.4 & 0.4 & 0.9 & 0.8 & 0.8 \\
\hline C24:0 & 0.7 & 0.3 & 0.6 & 1.1 & 1.4 & 0.4 & 2.4 & 1.7 & 1.5 & 0.5 & 0.8 & 1.5 & 2.2 & 1.0 \\
\hline Unsaturated & 63.0 & 66.7 & 65.4 & 60.7 & 40.0 & 63.5 & 36.5 & 44.1 & 38.4 & 65.0 & 64.0 & 52.6 & 58.9 & 34.0 \\
\hline C16-C18 & 97.3 & 98.2 & 97.8 & 97.2 & 96.6 & 98.0 & 94.6 & 95.8 & 94.9 & 98.0 & 97.4 & 96.2 & 95.3 & 96.5 \\
\hline
\end{tabular}

The fatty acid component is also an important indicator of suitability for biodiesel production. C16-C18 fatty acids can improve the combustion performance of biodiesel [39]. In addition, the increase of unsaturated fatty acids proportion can improve biodiesel's low-temperature flow properties [7]. For all the treatments in this study, the proportion of C16-C18 fatty acids exceeded 90\% of the total fatty acids, which was higher than the average value reported in the literature. Moreover, adding $2 \mathrm{mg} \mathrm{N} \mathrm{L}{ }^{-1}$ of $\mathrm{CH}_{4} \mathrm{~N}_{2} \mathrm{O}$ increased the proportion of $\mathrm{C} 16-\mathrm{C} 18$ and unsaturated fatty acids further, to 95.3\% and 58.9\%, respectively. Amin et al. [18] reported an increased proportion (63.6\%) of C16-C18 fatty acids when $41.2 \mathrm{mg} \mathrm{N} \mathrm{L}^{-1}$ of $\mathrm{CH}_{4} \mathrm{~N}_{2} \mathrm{O}$ was added to the medium. Yu et al. [7] reported that the proportion of $\mathrm{C} 16-\mathrm{C} 18$ fatty acids produced by the two-step cultivation method was approximately $80 \%$. The increase in the proportion of C16-C18 fatty acids in the current study suggested that multiple small-doses of nitrogen could improve both the combustion performance and low-temperature flow performance of biodiesel.

\section{Conclusions}

This study investigated the improvements of growth and lipid production of Scenedesmus obliquus by adding multiple small-doses of nitrogen. The highest biomass and lipid production were $1.7 \times 10^{7}$ cells mL $\mathrm{mL}^{-1}$ and $242.4 \mathrm{mg} \mathrm{L}^{-1}$, respectively, with the daily addition of $2 \mathrm{mg} \mathrm{N} \mathrm{L}^{-1}$ of $\mathrm{CH}_{4} \mathrm{~N}_{2} \mathrm{O}$. These values were significantly higher than those of the control sample $\left(1.0 \times 10^{7} \mathrm{cells} \mathrm{mL}^{-1}\right.$ and $87.9 \mathrm{mg} \mathrm{L}^{-1}$, respectively) and the two-step cultivation method $\left(6.3 \times 10^{6}\right.$ cells $\mathrm{mL}^{-1}$ and $91.8 \mathrm{mg} \mathrm{L}^{-1}$, respectively). In addition, the daily addition of $2 \mathrm{mg} \mathrm{N} \mathrm{L}^{-1}$ of $\mathrm{CH}_{4} \mathrm{~N}_{2} \mathrm{O}$ yielded a lutein content of Scenedesmus obliquus of $0.48 \mathrm{mg} \mathrm{L}^{-1}$, but this was insufficient to promote commercial production of lutein as a byproduct (which would have decreased the overall cost of lipid production). Therefore, further investigation should be performed to decrease the costs of lipid production of Scenedesmus obliquus through the high value co-produced pigment. This study demonstrated that adding multiple small-doses of nitrogen under nitrogen-starvation condition could improve lipid production, which could be applied to the large-scale biofuel production.

Author Contributions: Conceptualization, methodology, resources, validation, and project administration, M.L., L.G., and M.A.; software, and investigation, M.A., W.Z., and W.C.; formal analysis and writing-original draft, M.A. and M.L.; writing-review and editing and supervision, M.L. All authors have read and agreed to the published version of the manuscript.

Funding: This work was supported by the Fundamental Research Funds for Central Universities (Northwest A\&amp;F University, Grant No. 2452018142); Ming Li is funded as Tang Scholar by Cyrus Tang Foundation and Northwest A\&amp;F University.

Acknowledgments: We thank Sam Pickard, from Liwen Bianji, Edanz Group China (www.liwenbianji.cn/ac), for editing the English text of a draft of this manuscript.

Conflicts of Interest: The authors declare no conflict of interest. 


\section{References}

1. Sivaramakrishnan, R.; Incharoensakdi, A. Microalgae as feedstock for biodiesel production under ultrasound treatment-A review. Bioresour. Technol. 2018, 250, 877-887. [CrossRef] [PubMed]

2. Holmes, B.; Paddock, M.B.; VanderGheynst, J.S.; Higgins, B.T. Algal photosynthetic aeration increases the capacity of bacteria to degrade organics in wastewater. Biotechnolo. Bioeng. 2020, 117, 62-72. [CrossRef] [PubMed]

3. Nzayisenga, J.C.; Farge, X.; Groll, S.L.; Sellstedt, A. Effects of light intensity on growth and lipid production in microalgae grown in wastewater. Biotechnol. Biofuels 2020, 13, 1-8. [CrossRef] [PubMed]

4. Qu, Z.; Duan, P.; Cao, X.; Liu, M.; Lin, L.; Li, M. Comparison of monoculture and mixed culture (Scenedesmus obliquus and wild algae) for C, N, and P removal and lipid production. Environ. Sci. Pollut. Res. 2019, 26, 20961-20968. [CrossRef] [PubMed]

5. Peng, Q.; Zhao, M.; Shen, G.; Gan, X.; Li, M. Linear alkylbenzene sulfonate (LAS) promotes sedimentation and lipid accumulation in Scenedesmus obliquus. RSC Adv. 2017, 7, 9244-9250. [CrossRef]

6. De Oliveira, C.Y.B.; Viegas, T.L.; Lopes, R.G.; Cella, H.; Menezes, R.S.; Soares, A.T.; Filho, N.R.A.; Derner, R.B. A comparison of harvesting and drying methodologies on fatty acids composition of the green microalga Scenedesmus obliquus. Biomass Bioenergy 2020, 132. [CrossRef]

7. Yu, Z.; Pei, H.; Jiang, L.; Hou, Q.; Nie, C.; Zhang, L. Phytohormone addition coupled with nitrogen depletion almost tripled the lipid productivities in two algae. Bioresour. Technol. 2018, 247, 904-914. [CrossRef]

8. Singh, K.; Kaloni, D.; Gaur, S.; Kushwaha, S.; Mathur, G. Current research and perspectives on microalgae-derived biodiesel. Biofuels 2020, 11, 1-18. [CrossRef]

9. Nayak, M.; Suh, W.I.; Chang, Y.K.; Lee, B. Exploration of two-stage cultivation strategies using nitrogen starvation to maximize the lipid productivity in Chlorella sp. HS2. Bioresour. Technol. 2019, 276, 110-118. [CrossRef]

10. Pancha, I.; Chokshi, K.; George, B.; Ghosh, T.; Paliwal, C.; Maurya, R.; Mishra, S. Nitrogen stress triggered biochemical and morphological changes in the microalgae Scenedesmus sp. CCNM 1077. Bioresour. Technol. 2014, 156, 146-154. [CrossRef]

11. Jia, J.; Han, D.; Gerken, H.G.; Li, Y.; Sommerfeld, M.; Hu, Q.; Xu, J. Molecular mechanisms for photosynthetic carbon partitioning into storage neutral lipids in Nannochloropsis oceanica under nitrogen-depletion conditions. Algal Res. 2015, 7, 66-77. [CrossRef]

12. Converti, A.; Casazza, A.A.; Ortiz, E.Y.; Perego, P.; Borghi, M.D. Effect of temperature and nitrogen concentration on the growth and lipid content of Nannochloropsis oculata and Chlorella vulgaris for biodiesel production. Chem. Eng. Process. 2009, 48, 1146-1151. [CrossRef]

13. Lv, J.-M.; Cheng, L.-H.; Xu, X.-H.; Zhang, L.; Chen, H.-L. Enhanced lipid production of Chlorella vulgaris by adjustment of cultivation conditions. Bioresour. Technol. 2010, 101, 6797-6804. [CrossRef] [PubMed]

14. Qi, F.; Pei, H.; Ma, G.; Zhang, S.; Mu, R. Improving productivity and quality of biodiesel from Chlorella vulgaris SDEC-3M through customized process designs. Energy Convers. Manag. 2016, 129, 100-107. [CrossRef]

15. Sonkar, S.; Mallick, N. Development of a single phase nitrate feeding strategy for enhanced lipid productivity from green microalgae for biodiesel production. Environ. Prog. Sustain. Energy 2017, 36, 222-231. [CrossRef]

16. Han, F.; Huang, J.; Li, Y.; Wang, W.; Wan, M.; Shen, G.; Wang, J. Enhanced lipid productivity of chlorella pyrenoidosa through the culture strategy of semi-continuous cultivation with nitrogen limitation and $\mathrm{pH}$ control by $\mathrm{CO}_{2}$. Bioresour. Technol. 2013, 136, 418-424. [CrossRef] [PubMed]

17. Li, T.; Wan, L.; Li, A.; Zhang, C. Responses in growth, lipid accumulation, and fatty acid composition of four oleaginous microalgae to different nitrogen sources and concentrations. Chin. J. Oceanol. Limnol. 2013, 31, 1306-1314. [CrossRef]

18. Amin, N.F.; Khalafallah, M.A.; Ali, M.A.; Abou-Sdera, S.A.; Matter, I.A. Effect of some nitrogen sources on growth and lipid of microalgae Chlorella sp. for biodiesel production. J. Appl. Sci. Res. 2013, 9, 4845-4855.

19. Zhao, M.; Qu, D.; Shen, W.; Li, M. Effects of dissolved organic matter from different sources on Microcystis aeruginosa growth and physiological characteristics. Ecotoxicol. Environ. Saf. 2019, 176, 125-131. [CrossRef]

20. Gan, X.; Shen, G.; Xin, B.; Li, M. Simultaneous biological desalination and lipid production by Scenedesmus obliquus cultured with brackish water. Desalination 2016, 400,1-6. [CrossRef] 
21. Tian, Y.; Gao, L.; Deng, J.; Li, M. Characterization of phytoplankton community in a river ecosystem using pigment composition: A feasibility study. Environ. Sci. Pollut. R. 2019. [CrossRef] [PubMed]

22. Li, X.; Hu, H.; Gan, K.; Sun, Y. Effects of different nitrogen and phosphorus concentrations on the growth, nutrient uptake, and lipid accumulation of a freshwater microalga scenedesmus sp. Bioresour. Technol. 2010, 101, 5494-5500.

23. Ho, S.-H.; Chen, C.-Y.; Chang, J.-S. Effect of light intensity and nitrogen starvation on CO2 fixation and lipid/carbohydrate production of an indigenous microalga Scenedesmus obliquus CNW-N. Bioresour. Technol. 2012, 113, 244-252. [CrossRef] [PubMed]

24. Yong, W.K.; Lim, P.E.; Vello, V.; Sim, K.S.; Majid, N.A.; Mustafa, E.M.; Nik, S.N.M.; Liew, K.E.; Chen, B.J.T.; Phang, S.M. Metabolic and physiological regulation of Chlorella sp.(Trebouxiophyceae, Chlorophyta) under nitrogen deprivation. J. Oceanol. Limnol. 2019, 37, 186-198. [CrossRef]

25. Yu, Z.; Song, M.; Pei, H.; Jiang, L.; Hou, Q.; Nie, C.; Zhang, L. The effects of combined agricultural phytohormones on the growth, carbon partitioning and cell morphology of two screened algae. Bioresour. Technol. 2017, 239, 87-96. [CrossRef]

26. Salama, E.-S.; Kabra, A.N.; Ji, M.-K.; Kim, J.R.; Min, B.; Jeon, B.-H. Enhancement of microalgae growth and fatty acid content under the influence of phytohormones. Bioresour. Technol. 2014, 172, 97-103. [CrossRef]

27. Kichul, C.; Kilnam, K.; Nalae, L.; Moosang, K.; Jeongchul, H.; Hyeon, H.S.; Mikyung, K.; Seong, W.R.; Daekyung, K.; Tatsuya, O. Enhanced biomass and lipid production by supplement of myo-inositol with oceanic microalga Dunaliella salina. Biomass Bioenergy 2015, 72, 1-7.

28. Sangram, K.L.; Nicole, C.; Rudolph, P.; Stephen, M.M.; Ian, T.; Li, Y. Current advances in molecular, biochemical, and computational modeling analysis of microalgae triacylglycerol biosynthesis. Biotechnol. Adv. 2016, 34, 1046-1063.

29. Long, B.M.; Jones, G.J.; Orr, P.T. Cellular Microcystin Content in N-Limited Microcystis aeruginosa Can Be Predicted from Growth Rate. Appl. Environ. Microbiol. 2001, 67, 278-283. [CrossRef]

30. Qu, Z.; Zhao, M.; Duan, P.; Li, M. Effects of nitrogen forms and supply modes on colony formation in Microcystis aeruginosa. Environ. Boil. Fishes 2017, 30, 831-837. [CrossRef]

31. Von Ruckert, G.; Giani, A. Effect of nitrate and ammonium on the growth and protein concentration of Microcystis viridis Lemmermann (Cyanobacteria). Braz. J. Bot. 2004, 27, 325-331.

32. Kamyab, H.; Tin Lee, C.; Md Din, M.F.; Ponraj, M.; Eva Mohamad, S.; Sohrabi, M. Effects of nitrogen source on enhancing growth conditions of green algae to produce higher lipid. Desalin. Water Treat. 2014, 52, 3579-3584. [CrossRef]

33. Liu, N.; Zhang, H.; Zhao, J.; Xu, Y.; Ge, F. Mechanisms of cetyltrimethyl ammonium chloride-induced toxicity to photosystem II oxygen evolution complex of Chlorella vulgaris F1068. J. Hazard. Mater. 2020, 383. [CrossRef] [PubMed]

34. Rodolfi, L.; Chini Zittelli, G.; Bassi, N.; Padovani, G.; Biondi, N.; Bonini, G.; Tredici, M.R. Microalgae for oil: Strain selection, induction of lipid synthesis and outdoor mass cultivation in a low-cost photobioreactor. Biotechnol. Bioeng. 2009, 102, 100-112. [CrossRef]

35. Babu, A.G.; Wu, X.; Kabra, A.N.; Kim, D.-P. Cultivation of an indigenous Chlorella sorokiniana with phytohormones for biomass and lipid production under N-limitation. Algal Res. 2017, 23, 178-185. [CrossRef]

36. Del Campo, J. Carotenoid content of chlorophycean microalgae: Factors determining lutein accumulation in Muriellopsis sp. (Chlorophyta). J. Biotechnol. 2000, 76, 51-59. [CrossRef]

37. Del Campo, J.A.; Moreno, J.; Rivas, J.; Guerrero, M.G. Accumulation of astaxanthin and lutein in Chlorella zofingiensis (Chlorophyta). Appl. Microbiol. Biotechnol. 2004, 64, 848-854. [CrossRef]

38. Marella, T.K.; Datta, A.; Patil, M.D.; Dixit, S.; Tiwari, A. Biodiesel production through algal cultivation in urban wastewater using algal floway. Bioresour. Technol. 2019, 280, 222-228. [CrossRef]

39. Sung, Y.J.; Patel, A.K.; Yu, B.S.; Choi, H.I.; Kim, J.; Jin, E.; Sim, S.J. Sedimentation rate-based screening of oleaginous microalgae for utilization as a direct combustion fuel. Bioresour. Technol. 2019, 293. [CrossRef]

(C) 2020 by the authors. Licensee MDPI, Basel, Switzerland. This article is an open access article distributed under the terms and conditions of the Creative Commons Attribution (CC BY) license (http://creativecommons.org/licenses/by/4.0/). 